\title{
The species of the genus Crataegus L. in the National Nature Park 'Podilskyi Tovtry' (Podolian Hills, Western Ukraine)
}

\author{
Anna Sołtys-Lelek ${ }^{1 *} \&$ Halyna Oliiar ${ }^{2}$
}

${ }^{1}$ Ojców National Park, 32-045 Sułoszowa, Ojców 9, Poland

${ }^{2}$ Medobory Nature Reserve, Mitskevycha 21, 48210, smt. Hrymailiv, Husiatynskyi raion, Ternopilska Oblast, Ukraine

* corresponding author (e-mail: ana_soltys@wp.eu)

\begin{abstract}
The paper presents an inventory of hawthorns occurring in the National Nature Park 'Podilskyi Tovtry'. 8 taxa were recorded based on the field studies during the years 2009-2013, as well as on the published data. Four of them are new for the flora of the Park's area: $C$. $\times$ macrocarpa Hegetschw., $C$. $\times$ subsphaericea Gand., $C . \times$ media Bechst., and the triple hybrid $C$. monogyna Jacq. $\times$ C. laevigata (Pior.) DC. $\times$ C. rhipidophylla Gand.
\end{abstract}

Key words: hawthorns, hybrids, inventory, new data

\section{Introduction}

The genus Crataegus is taxonomically a very difficult group of plants. High polymorphism within this genus is the result of hybridisation and apomixis, however, in case of Euro-Asiatic hawthorns, the main identification problem results from hybridization, while for American species - mainly from apomixis (Muniyamma \& Phipps 1979; Christensen 1992; Talent $\&$ Dickinson 2005). Apart from such a high morphological differentiation, also the previous numerous changes in classification criteria sorted out many species. For instance, C. monogyna - the most variable species, considering its leaf blade shape, was divided into a few taxa. Therefore, the data records contained in former papers, require revision based on recent taxonomic studies, e.g. Christensen (1992), Phipps et al. (2003) or Kurtto et al. (2013), which present the solution to most taxonomic problems.

The general knowledge of hawthorn distribution in the National Nature Park 'Podilskyi Tovtry' (NNPPT) is fairly poor. Although, the studies of Park's flora have been carried since the $19^{\text {th }}$ century, they focused mainly on general distribution of vascular plants. Hence, only a few species of Crataegus were recorded. Besser (1882) published the first reports on two hawthorn species of occurring in the Park's area: Crataegus monogyna Jacq. and C. laciniata Stev. (= C. rhipidophylla Gand.). In 1999, the complete list of NNPPT flora (Lyubinska et al. 1999) was published, that included six hawthorn species: Crataegus curvisepala Lindm. (= C. rhipidophylla), C. leiomonogyna Klokov (= C. monogyna), C. lipskyi Klokov (= C. monogyna), C. pentagyna Waldst. et Kit., C. praearmata Klokov (=C. monogyna) and C. pseudokyrtostyla Klokov (=C. rhipidophylla). Within this group, five species are considered synonymous according to the recent taxonomic nomenclature (Christensen 1992, 1997; Janjić 2002). The mentioned species were also reported by Klokov (1954) in the Flora USSR and by Novosad et al. (2009). The list of hawthorns occurring in the Park's area was completed by Crataegus coccinea L. (Levanets et al. 2004).

In conclusion, based on the newest nomenclature (Christensen 1992, 1997; Janjić 2002), it is possible to say that until 2009, three native and one antropophyte hawthorn species were found in the NNPPT area. Afterwards, more studies on the Park's hawthorn species were conducted. The goal of this paper was to provide a comprehensive list of hawthorns presently occurring within the Park's limits, based on the current taxonomic terminology of Christensen $(1992,1997)$ and Janjić (2002), complemented by the list of their localities. 


\section{Study area}

The National Nature Park 'Podilskyi Tovtry' (NNPPT) was established in 1996. It is situated on the territory of Kamianets-Podilskyi, Chemerovtsi and part of Horodok districts of Khmelnytskyi Oblast (province) in the southern region of western Ukraine. The Park covers 261,316 ha. Considering the geophysical division, the southern part of the Park belongs to the Prut-Dniester highland region, while its middle and northern parts belong to the West Podilskyi highland region (Pylypyuk 2008; geomap.land.kiev.ua/zoning1. html; tovtry.com).
The Tovtry are the mountain range attaining a height of $401 \mathrm{~m}$ a.s.l. within the Park's limits. The ridge was formed 40-25 million years ago. It was formed of coral reef, water plants and mollusks, and consists of different types of limestone, elevated due to tectonic movements. 2977 plant species requiring different ecological conditions occur in the NNPPT area. Among them, there are about 30 endemic species. The microclimate of the Transnistria region is shaped by the Tovtry Ridge and canyons of the Dnister River and its tributaries (Pylypyuk 2008; tovtry.com). The 'Podilskyi Tovtry' National Nature Park plays an important role in protecting the biodiversity of the Polodia region.

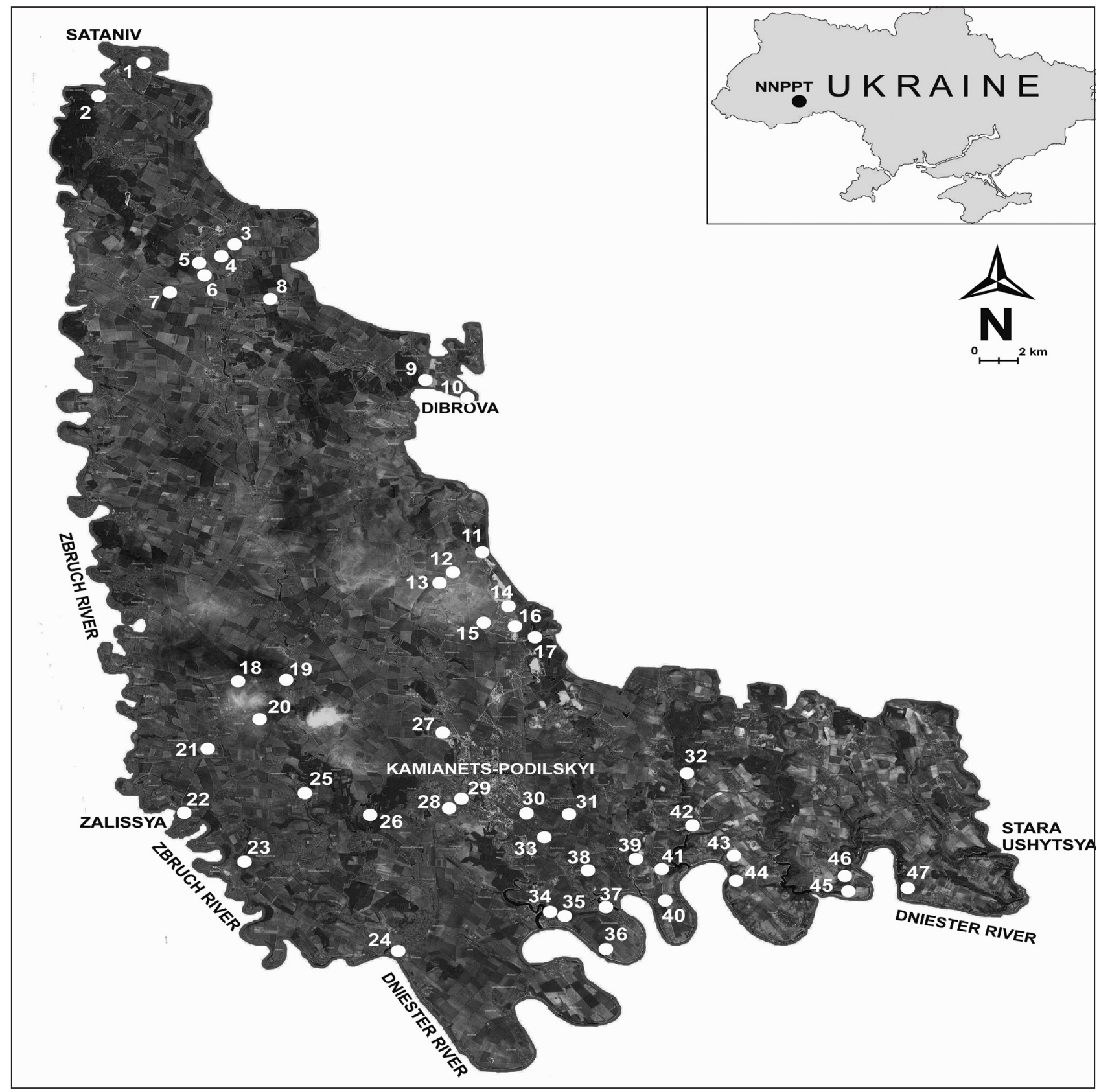

Fig. 1. Location of localities in the study area Explanation: list of localities cf. Appendix 1 
The biggest part of the Park (ca 75\%) is occupied by agricultural areas, while forests and natural vegetation cover nearly $15 \%$ of the Park's territory. The natural vegetation cover is formed by oak, mixed hornbeamoak-ash and beach forests, patches of xerothermic grasslands and meadows (Lyubinska 2013).

\section{Material and methods}

Herbarium material, containing flowering short shoots, was collected in 2009-2013. The localities of common and easy to identify in the field taxa, such as Crataegus monogyna were only sporadically collected. The correctness of identification of atypical forms was verified by Prof. K. I. Christensen from the Natural History Museum of Denmark. All herbarium materials were deposited in the Herbarium of the Ojców National Park (Ojców, Poland).

Data were collected in 47 localities (Fig. 1, Appendix 1). The names of places were based on google.pl/maps. The names of localities were supplemented with the abbreviation of the author's name and the year when field observations or specimen collection were conducted. Data from the literature were also included. Taxonomic approach was based on the works of Christensen (1992, 1997) and Janjić (2002), while the nomenclature is after Christensen (1992, 1997), Janjić (2002), Phipps et al. (2003) and the International Plant Names Index (IPNI) (ipni.org/index.html).

The geographical elements for each species follow Christensen (1992), Kurtto et al. (2013) and Zając \& Zając (2009). For an anthropophyte, its native range was given.

\section{Results}

The list contains 8 taxa of hawthorns, belonging to the series: Pentagynae (C. K. Schneid.) Russanov (1 species), Crataegus (6 taxa) and Coccineae (Loudon) Rehder ( 1 species). Among them, 6 native taxa (including 3 native hybrid forms at the level of species), 1 anthropophyte and 1 triple-hybrid form.

Four new taxa for the flora of the National Nature Park were found during the study. These are: $C . \times m a c-$ rocarpa Hegetschw., C. ×subsphaericea Gand., $C$. $\times$ media Bechst. and a triple hybrid C. monogyna Jacq. $\times$ C. laevigata (Pior.) DC. $\times$ C. rhipidophylla Gand.

C. $\times$ media, C. pentagyna and C. pedicellata, found in single localities, were the rarest hawthorns occurring in the studied area, while the most frequent were: C. monogyna (46 localities) and $C . \times$ subsphaericea (12 localities).

Taxonomic list of species of the genus Crataegus L.

Abbreviations and symbols: SL - Anna Sołtys-Lelek, leg. - legitimate, obs. - observation, OPN - Herbarium of the Ojców National Park
Geographical e lements: CE-Europeantemperate sub-element, $\mathrm{M}$ - Mediterranean element, NS - Nearctic-Subatlantic element, IR - IranoTuranian element, PAN-PONT - Pontic-Pannonian sub-element. Additional symbols: e - eastern, w western.

\section{Ser. Pentagynae}

Crataegus pentagyna Waldst. \& Kit. ex Willd.

Geographical element: PAN-PONT

Distribution in the Ukraine: The range limited to Podolia and the north-eastern and eastern parts of the country (Christensen 1992; Kurtto et al. 2013).

Study a rea: Reported from only one localityZhvanets (Klokov 1954).

\section{Ser. Crataegus \\ Subser. Crataegus}

Crataegus rhipidophylla Gand. (Syn.: C. curvisepala Lindm., C. laciniata Stev., C. pseudokyrtostyla Klokov)

Geographical element: CE-M(e)-IR(w)

Distribution in the Ukraine: Numerous localities in the whole area of the country (Kurtto et al. 2013).

Study area: The species reported as widespread in the study area under the names: $C$. laciniata Stev. (Besser 1822), C. curvisepala Lindm. and C. pseudokyrtostyla Klokov (Lyubinska et al. 1999; Klokov 1954; Novosad et al. 2009). Nowadays, two varieties reported from eight localities:

- var. rhipidophylla

Geographical element: CE-M(e)-IR(w)

Study area: 7 localities - 17, 27 (leg. SL 2010);

6, 11, 12, 20, 40 (leg. SL 2013).

- var. ronnigeri (K. Malý) Janjić

Geographical element: CE

Study area: 1 locality - 36 (leg. SL 2013).

Crataegus monogyna Jacq. var. monogyna (Syn.: $C$. leiomonogyna Klokov, C. lipskyi Klokov, C. praearmata Klokov)

Geographical element: CE-M(e)-IR(w)

Distribution in the Ukraine: the species occurs in large numbers in localities distributed throughout the country, especially common in western Ukraine (Kurtto et al. 2013).

Study a rea: One variety reported from 46 localities scattered in the whole study area. 44 localities: 2 (leg. SL 2009); 33 (leg. SL 2010); 5, 6, 11, 13, 14, 16, $20,22,23,25,31,34,35,37,40,42,44,45$ (leg. SL 2013); Observations: 17, 27, 30, 32 (obs. SL 2010); $1,3,4,7,8,9,10,12,15,18,19,21,26,36,38,39$, 41, 43, 46, 47 (obs. SL 2013); Literature: Dovzhok 
(Klokov 1954), Kamianets-Podilskyi (Levanets 2004).

Crataegus $\times$ macrocarpa Hegetschw. [C. laevigata $\times C$. rhipidophylla ] (Fig. 2)

Geographical element: CE

Distribution in the Ukraine: the taxon endemic in Europe, reported earlier from the Ukraine by Klokov (1954) as Crataegus calycina Peterm. from the Carpathians and Zakarpacie and the Lviv area. Crataegus calycina Peterm. was reported by Tzvelev (2001) from the Crimea as a cultivated plant and $C$. ×macrocarpa occurs in natural habitats. The later data on the occurrence of this nothospecies in Ukraine come from the western part of Podolia and Roztocze regions (Sołtys-Lelek 2012; Sołtys-Lelek \& Barabasz-Krasny 2013). However, it should be noted, that distribution of this taxon in Ukraine requires further study.

Study area: A new taxon for the Park's flora, reported in two nothovarieties:

- C. ×macrocarpa nothovar. macrocarpa [C. laevigata $\times$ C. rhipidophylla var. rhipidophylla] 8 localities: 17, 32 (leg. SL 2010); 9, 11, 13, 16, 20, 44 (leg. SL 2013).

- C. ×macrocarpa nothovar. calycina (Peterm.) Kerguélen $[$ C. laevigata $\times C$. rhipidophylla var. ronnigeri]

1 locality: 13 (leg. SL 2013).

Crataegus $\times$ subsphaericea Gand. nothovar. subsphaericea $[C$. monogyna $\times C$. rhipidophylla var. rhipidophylla]

Geographical element: CE-M(e)-IR(w)

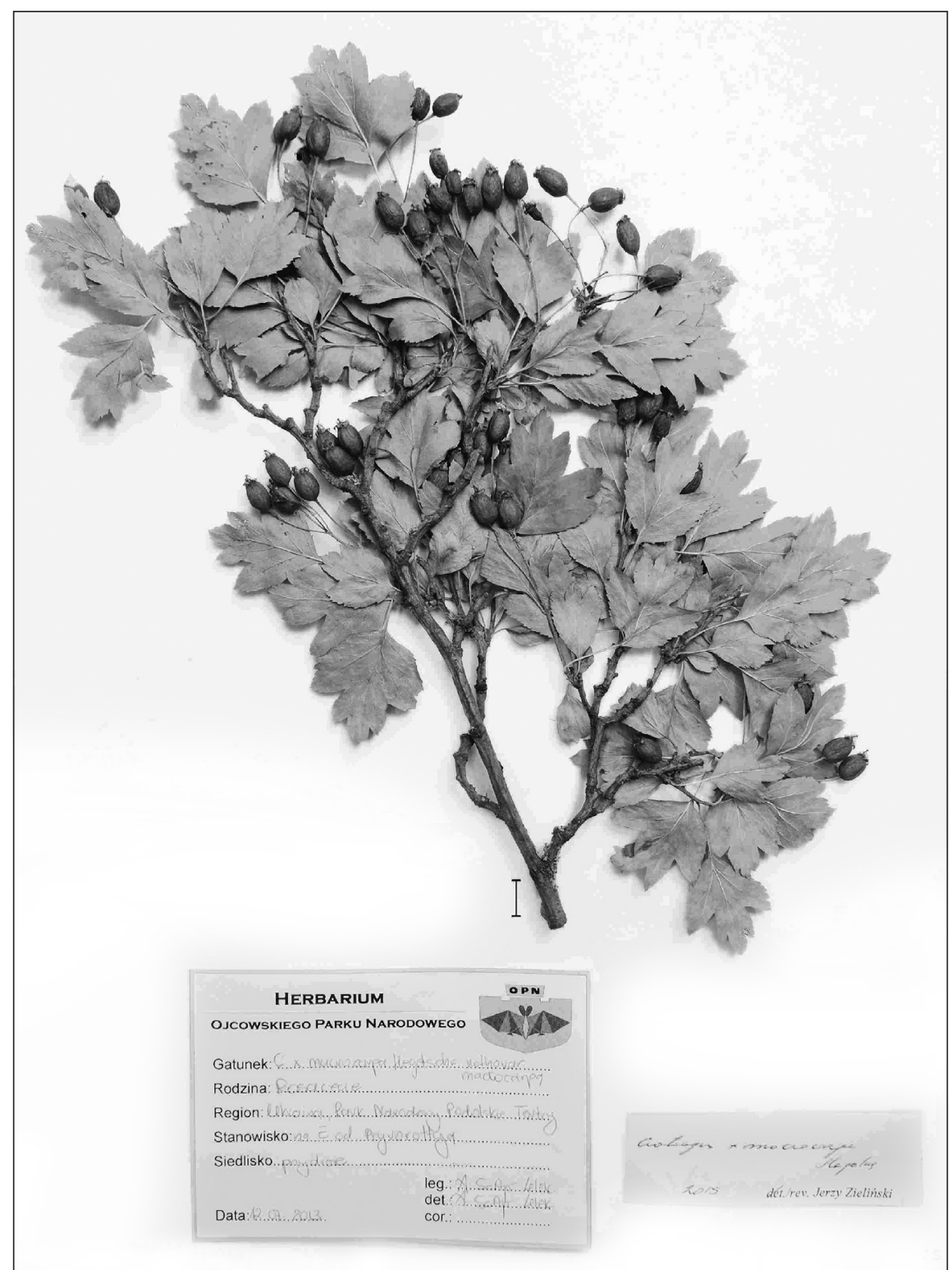

Fig. 2. Crataegus $\times$ macrocarpa nothovar. macrocarpa - a flowering shoot. The National Park 'Podilskyi Tovtry', E of Pryvorottia. Solid bar $=1 \mathrm{~cm}$ (Herbarium of the Ojców National Park, Ojców) 
Distribution in the Ukraine: the nothospecies occurs in few localities scattered in the whole country (Christensen 1992).

Study area: A new taxon for the Park's flora, reported in one nothovariety from 12 localities scattered in the whole study area. 12 localities: 2 (leg. SL 2009); 17, 27, 30, 32, 33 (leg. SL 2010); 5, 8, 12, 13, 41, 42 (leg. SL 2013).

Crataegus $\times$ media Bechst. nothovar. media $-[$ C. laevigata $\times$ C. monogyna] (Fig. 3)

Geographical element: CE-M

Distribution in the Ukraine: the nothospecies occurs in few scattered localities (Kormilitsin 1960; Sołtys-Lelek 2012; Sołtys-Lelek $\&$ Barabasz-Krasny 2013). The taxon was reported earlier as Crataegus oxyacantha f. rosea (Kormil- itsin 1960). Distribution of $C$. ×media in Ukraine requires further study.

St udy a rea: The new nothospecies for the Park's flora, reported only from one locality - 33 (leg. SL 2010).

Crataegus monogyna Jacq. $\times$ C. laevigata (Pior.) DC. $\times$ C. rhipidophylla Gand.

A triple hybrid form that occurs within its parent species range. The hybrid was reported also, among others, from Poland, Czech and Slovak Republic (Holub 1992; Marciniuk \& Oklejewicz 2012; Oklejewicz \& Vončina 2012; Oklejewicz et al. 2013, 2014; Sołtys-Lelek et al. 2014). Its distribution and determination of geographical range requires further study.

Distribution in the Ukraine: Thehybrid not previously reported from the Ukraine.

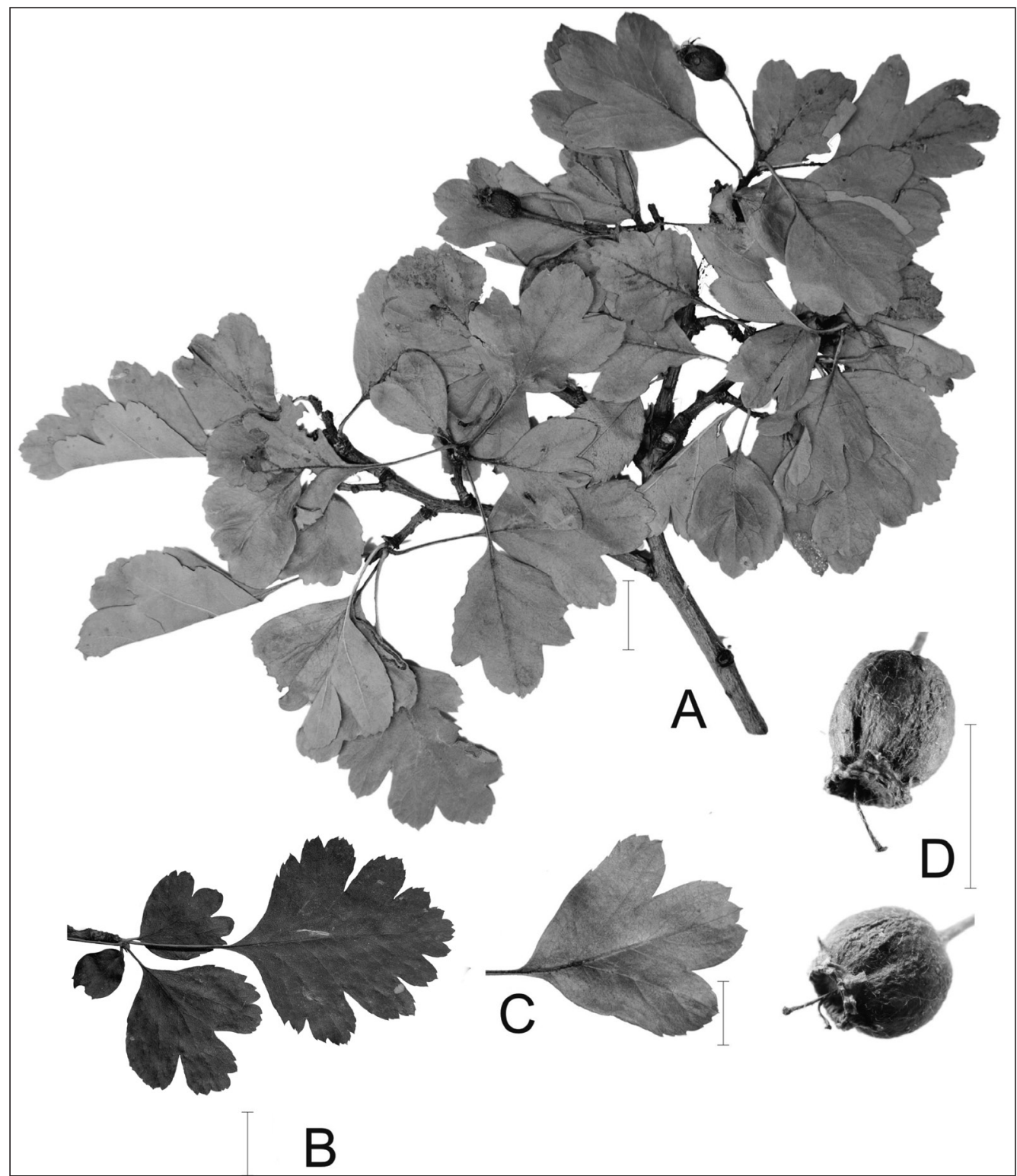

Fig. 3. Crataegus $\times$ media nothovar. media. A: part of flowering shoot, B: short shoot, C: subterminal leaf of flowering short shoot, D: pome. Solid bar $=1 \mathrm{~cm}$ (Herbarium of the Ojców National Park, Ojców) 
Study area: Found in only one locality -12 (leg. SL 2013, OPN).

\section{Ser. Coccineae}

Crataegus coccinea L. (Syn.: C. pedicellata Sarg.) Anthropophyte, native range: NS Distribution in the Ukraine: an exotic species cultivated in botanical gardens and parks (Mosyakin \& Fedoronchuk 1999).

Study area: Reported from only one localityKamianets-Podilskyi (Levanets 2004).

\section{Discussion}

In this study, the eight taxa of the genus Crataegus L. are reported from the National Nature Park 'Podilskyi Tovtry' and a new taxonomic classification is presented based on Christensen $(1992,1997)$ and Janjić (2002). Christensen listed the criteria for species identification and introduced a new taxonomic nomenclature for the hawthorns in Europe, while Janjić corrected the nomen- clature of Crataegus rhipidophylla.

The hawthorn species known so far from the NNPPT area were identified based on Klokov (1954). The very narrow taxonomic study of species reported in the paper required the detailed investigation of these taxa. According to the recent taxonomic nomenclature of hawthorns by Christensen $(1992,1997)$, most of previously classified taxa are currently categorised as synonymous ones. Based on the above papers - only the taxonomic status of Crataegus monogyna Jacq., C. pentagyna Waldst. et Kit. and $C$. coccinea $\mathrm{L}$. has not changed on the NNPPT list of hawthorns. The Crataegus leiomonogyna Klokov, C. lipskyi Klokov and C. praearmata Klokov were incorporated into C. monogyna Jacq., while C. laciniata Stev., C. curvisepala Lindm., and C. pseudokyrtostyla Klokov into C. rhipidophylla Gand.

A triple hybrid $C$. monogyna $\times C$. laevigata $\times C$. rhipidophylla seems to be one of more interesting taxa in the studied area. The precise range of its occurrence has not been defined yet. It might be supposed that its distribution approximately coincides with the paren-

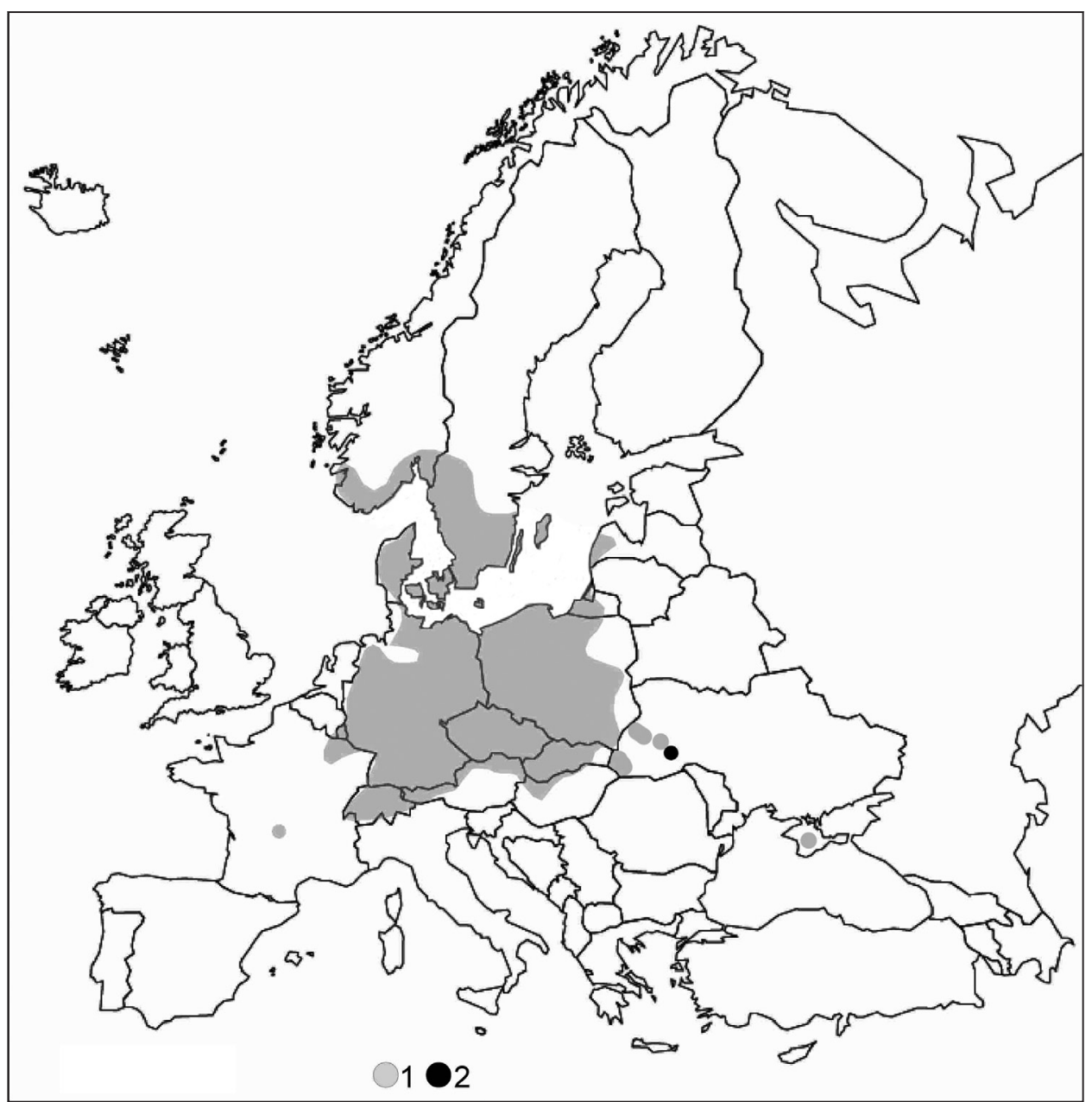

Fig. 4. Geographical range of Crataegus ×macrocarpa in Europe (according to Klokov 1954; Christensen 1992; Tzvelev 2001; Sołtys-Lelek 2011, 2012; Kurtto et al. 2013; Sołtys-Lelek \& Barabasz-Krasny 2013; Oklejewicz et al. 2014, 2015)

Explanations: 1 - range, 2 - locality in NNPPT 
tal species occurrence. So far, the hybrid was found in the south-eastern part of Poland (Ciechanowska Upland, Bieszczady Mountains, Western Carpathians, Pieniny Mountains and Strzyżowskie Foothills), Slovak Republic (Low Tatras National Park) and Czech Republic (Czeskomorawski Massif, České středohoří Protected Landscape Area, Moravskoslezské Beskydy Mountains) (Holub 1992; Oklejewicz \& Vončina 2012; Oklejewicz et al. 2013, 2014, 2015; Sołtys-Lelek et al. 2014). It has not been reported from the territory of Ukraine so far. Considering so numerous data provided (its distribution, taxonomic status), this hybrid requires further studies.

C. pentagyna and $C . \times$ subsphaericea are very rare in Ukraine. C. pentagyna occurs mainly in the eastern part of the country (East from the Dnieper River: the Dnieper lowland, Central Russian Upland, Donetsk height), in Crimea and Podolia - the south part of Ukraine (Kurtto et al. 2013). Through Ukraine runs the western limit of the species range. C. $\times$ subsphaericea, was also reported from numerous sites occurring both in the eastern part of the country and Crimea territory, while in the western part of Ukraine - only from Volhynia (Christensen 1992). Its newly found localities in Podolia and Roztocze (Sołtys-Lelek 2012; Sołtys-Lelek \& Barabasz-Krasny 2013) clearly confirm that the status of this nothospecies distribution in Ukraine has not been fully assessed yet.

The new taxa of the National Nature Park flora are very interesting, especially those, not earlier reported, like: C. ×macrocarpa and C. ×media. According to Christensen (1992) and Kurtto et al. (2013), the range of these species is limited mainly to the middle and western part of European territory, while through Poland runs their east range limit. C. ×macrocarpa occurs sporadically in scattered localities throughout the Ukraine (Klokov 1954; Tzvelev 2001; Sołtys-Lelek 2012; Soltys-Lelek \& Barabasz-Krasny 2013). It was reported earlier as Crataegus calycina Peterm. (Klokov 1954) In the monographs by Christensen (1992) and Kurtto et al. (2013), the localities of the mentioned nothospecies were not reported. This may result from the lack

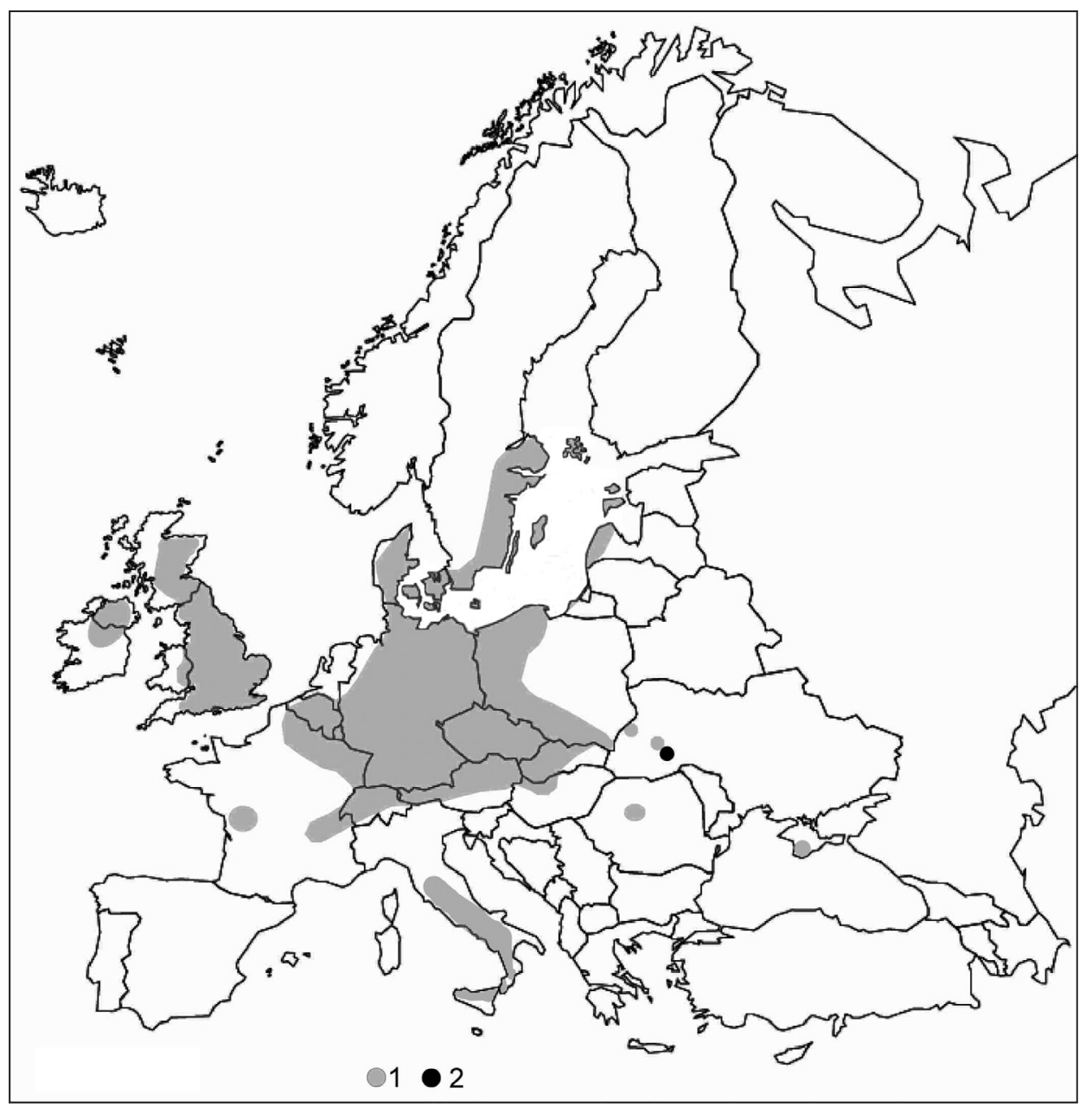

Fig. 5. Geographical range of Crataegus ×media in Europe (according to Christensen 1992; Sołtys-Lelek 2011, 2012; Sołtys-Lelek \& Barabasz-Krasny 2013; Oklejewicz et al. 2014, 2015; https://data.nbn.org.uk/Taxa/NHMSYS0001754310) Explanations: 1 - range, 2 - locality in NNPPT 
of sufficient studies on the species distribution. Due to the extremely large area, the provided data concerning the territory of Ukraine are not sufficient. Additionally, the genus requires more studies focused on the recent taxonomic terminology. $C$. $\times$ media hybrid occurs in few scattered localities in Ukraine. According to Christensen (1992), the eastern range limit of this taxon runs through Poland. It has been reported earlier from the Ukraine territory - Crimea (Kormilitsin 1960), Podolia (SołtysLelek 2012) and Roztocze (Sołtys-Lelek \& BarabaszKrasny 2013). The range limits of both studied taxa were presented on Figs. 4 and 5, although their present distribution in the Ukraine requires further detailed studies.

Considering geographical elements and geographical distribution, the abundance of individual hawthorn species in the flora of explored area is differentiated. In NNPPT dominate species belonging to the Europeantemperate and European-temperate-MediterraneanIrano-Turanian elements.

C. pentagyna - represents the Pontic-Pannonian subelement and is typical of the south-east steppe territory of Europe. It belongs to more interesting geographical elements in this part of Ukraine.

The results obtained during this study, complement the information about the distribution of hawthorns in this part of Ukraine and provide new data on the general hawthorn species distribution in Europe. However, it is important to mention, that the studies conducted so far do not exclude the occurrence of other localities of rare hawthorn species.

\section{References}

Besser W. 1822. Enumeratio Plantarum hucusque in Volhynia, Podolia, gub. Kiioviensi, Bessarabiia Cis-Tyraica et Circa Odessam Collectarum, Simul cum Observationibus in Primitas Florae Galiciae Austriacae. 27 pp. Wilna.

Christensen K. I. 1992. Revision of Crataegus Sect. Crataegus and Nothosect. Crataeguineae (RosaceaeMaloideae) in the Old World. Systematic Botany Monographs 35: 1-199.

CHRISTENSEN K. I. 1997. Typification of Crataegus kyrtostyla Fingerh. In: R. WisSKIRCHEN (ed.). Notulae ad Ffloram Germanicam I. Feddes Repertorium 108(1-2): 1-104.

Holub J. 1992. Crataegus L. In: S. HejnÝ, B. Slavík, J. KIRSCHNER \& B. KŘıǏ́A (eds.). Květena České republiky, 3, pp. 488-525. Academia Praha.

https://data.nbn.org.uk/Taxa/NHMSYS0001754310

http://geomap.land.kiev.ua/zoning1.html

http://www.ipni.org/index.html

http://www.tovtry.com

JANJIĆ N. 2002. Nova kombinacija u lepezolisnog ili krivočašičnog gloga, Crataegus rhipidophylla Gand. (Rosaceae). Works of Faculty of Forestry 1: 1-7.

Klokov M. V. 1954. Crataegus L. In: D. K. Zerov (ed.). Flora URSR, 6, pp. 49-79. National Academy of Sciences of Ukraine, Kiev.

Kormilitsin A. M. 1960. Trees and shrubs of the State Arboretum of Nikitsky Botanical Gardens. Works on dendrology and decor. Gardening 32: 173-213.

Kurtto A., Sennikov A. N. \& Lampinen R. (eds.) 2013. Atlas Florae Europaeae. Distribution of Vascular Plants in Europe. Rosaceae (Cydonia to Prunus, excl. Sorbus), 16, pp. 81-114. The Committee for Mapping the Flora of Europe \& Societas Biologica Fennica Vanamo, Helsinki.

Levanets A. A., Shevera M. V. \& Manturova J. V. 2004. Biodiversity of Kamianets-Podilskyi. Preliminary critical inventarisation checklist of plants, fungy and animals, pp. 82-135. Liga-Pres, L’viv.
Lyubinska L. H. 2013. Biotopes of National Nature Park 'Podilskyi Tovtry'. Chornomorski Botanical Journal 9(3): 459-467.

Lyubinska L. H., Kovalchuk S. I. \& Matveiev M. D. 1999. Pryrodni Tsinnosti Natsionalnoho Pryrodnoho Parku 'Podilskyi Tovtry'. Zatverdzheno haukovo-tekhnichnoiu radoiu Natsional'noho Pryrodnoho Parku 'Podilskyi Tovtry'. 51 pp. Kamianets-Podilskyi.

Marciniuk P. \& Oklejewicz K. 2012. Genera Rubus and Crataegus (Rosaceae) in Wysoczyzna Ciechanowska region. Fragm. Flor. Geobot. Polonica 19(2): 415-419.

Mezhenska L. O. \& Mezhenskyj V. M. 2013. Genus Hawtorn (Crataegus L.) in Ukraine: Introduction, Breeding, and Eco-biological Characteristics. Comprint, 234 pp. Kiev.

Mosyakin S. L. \& FedoronchuK M. M. 1999. Vascular plants of Ukraine: A nomenclatural checklist. 345 pp. M. G. Kholodny Institute of Botany, Kiev.

Muniyamma M. \& Phipps J. B. 1979. Cytological Proof of Apomixis in Crataegus (Rosaceae). Am. J. Bot. 66(2): 149-155.

Novosad V. V., Krytska L. I. \& Lyubinska L. H. 2009. Fitobiota Natsionalnoho Pryridnoho Parku 'Podilskyi Tovtry’. Sudynni roslyny, fito-ta flororiznomanittia anotovanyi konspekt spontannoï flory, II. 292 pp. Kiev.

OKlejewicz K. \& Vončina G. 2012. Rodzaj Crataegus w Pieninach. Pieniny - Przyroda i Człowiek 12: 71-79.

Oklejewicz K., Chwastek E., Szewczyk M., Bobiec A. \& MitкA J. 2013. - Distribution of Crataegus (Rosaceae) in S-E Poland along a gradient of anthropogenic influence. Polish Journal of Ecology 61(4): 683-691.

Oklejewicz K., Chwastek E., Szewczyk M., Ortyl B. \& MitKA J. 2014. Chorologiczne aspekty występowania głogów w Karpatach Polskich. 210 pp. Wyd. Uniwersytetu Rzeszowskiego, Rzeszów.

Oklejewicz K., Szewczyk M. \& Wolanin M. 2015. Rodzaj Crataegus w Bieszczadach. Roczniki Bieszczadzkie 23: $55-70$. 
Phipps J. B., Cafferty S. \& Macklin J. A. 2003. Lectotypification of Crataegus coccinea L. and its conspecificity with C. pedicellata Sarg. (Rosaceae). Taxon 52: 337-338.

PylYPYuK V. 2008. My Ukraine. Light and Shadow. 272 pp. Lviv.

Soztys-Lelek A. 2011. Chorologia krytycznych rodzajów - Crataegus L., Rosa L., Rubus L. na Wyżynie Krakowsko-Częstochowskiej. Prądnik. Prace Muzeum im. W. Szafera 21: 5-109.

Soetys-Lelek A. 2012. Genus Crataegus of the Medobory Nature Reserve and its protection zone (Podolian Hills, Western Ukraine). Visnyk of the Lviv University. Series Biology 59: 89-99.

Soltys-Lelek A. \& Barabasz-Krasny B. 2013. Genera Crataegus L. and Rosa L. of the Biosphere Reserve "Roztochya" and adjacent areas (Roztochya [Roztocze] Hills, Western Ukraine). Visnyk of the Lviv University. Series Biology 63: 86-97.
Soltys-Lelek A., Barabasz-Krasny B., Turis P. \& TurisoVÁ I. 2014. Chorológia niektorých taxónov kritických rodov Crataegus L. a Rosa L. vo vybraných častiach Národného parku Nízke Tatry. Part III. Naturae Tutela 18(1): 29-38.

Talent N. \& Dickinson T. A. 2005. Polyploidy in Crataegus and Mespilus (Rosaceae, Maloideae): evolutionary inferences from flow cytometry of nuclear DNA amounts. Botany 83(10): 1268-1304.

Tzvelev N. N. 2001. Genus 38. Crataegus L. In: N. N. Tzvelev (ed.). Flora of Eastern Europe. St. Petersburg 10: 557-586.

ZAJAC M. \& ZAJAC A. 2009. The geographical elements of native flora of Poland. $94 \mathrm{pp}$. Edited by Laboratory of Computer Chorology, Institute of Botany, Jagiellonian University, Cracow. 
Appendix 1. List of hawthorn localities in the National Park 'Podilskyi Tovtry' with geographical coordinates

\begin{tabular}{|c|c|c|}
\hline No. & Locality & Coordinates \\
\hline 1 & Sataniv - part E & N49015'33" E26015'24" \\
\hline 2 & SE of Sataniv & N49013'58" E26014'5" \\
\hline 3 & Zakupne - quarry & N4906'46" E26021'34" \\
\hline 4 & Zakupne & N4906'17" E26021'11" \\
\hline 5 & Zakupne - quarry 1 & N4906'14" E26019'44" \\
\hline 6 & S of Zakupne & N4905'41" E26019'53" \\
\hline 7 & E of Vilhivtsi & N4904'47" E26017'32" \\
\hline 8 & Demkivtsi & N4904'14" E26023'44" \\
\hline 9 & $\mathrm{~N}$ of Smotrych & N48059'46" E26033'13" \\
\hline 10 & Horodok & N48058'18" E26033'14" \\
\hline 11 & $\mathrm{~S}$ of Smotrych & N48051'44" E26036'14" \\
\hline 12 & Nihyn $-\mathrm{N}$ part & N48050'47" E26033'42" \\
\hline 13 & Nihyn - tovtry & N48050'20" E26033'4" \\
\hline 14 & Verbka $-\mathrm{N}$ part & N48049'9" E26037'26" \\
\hline 15 & Verbka Tovtry & N48048'28" E26036'5" \\
\hline 16 & Verbka - near quarry, rocks & N48047'54" E26037'28" \\
\hline 17 & Pryvorottia II & N48047'36" E26038'57" \\
\hline 18 & W of Orynyn & N48045'55" E26020'0" \\
\hline 19 & Orynyn & N48045'49" E26022'7" \\
\hline 20 & E of Pryvorottia & N48044'43" E26021'6" \\
\hline 21 & Adamivka & N48042'55" E26018'38" \\
\hline 22 & Chornokozyntsi & N48039'56" E26016'55" \\
\hline 23 & W of Kizya Kudrynetska & N48037'22" E26019'20" \\
\hline 24 & Zhvanets & N48033'0.5" E26029'28" \\
\hline 25 & W of Liskivtsi & N48040'18" E26023'1" \\
\hline 26 & Surzha & N48039'41" E26029'25" \\
\hline 27 & Pudlivtsi & N48043'23" E26033'3" \\
\hline 28 & Dovzhok & N48040'13" E26031'17" \\
\hline 29 & Kamianets-Podilskyi & N48040'11" E26033'52" \\
\hline 30 & Zhovtneve & N48039'25" E26037'40" \\
\hline 31 & Slobidka-Kulchiievetska & N48039'21" E26039'58" \\
\hline 32 & Surzhynieckyi Ravine & N48040'55" E26047'25" \\
\hline 33 & Mukshanskyi Reserve & N48038'10" E26038'40" \\
\hline 34 & $\mathrm{~N}$ of Ustia & N48034'44" E26038'37" \\
\hline 35 & NE of Ustia & N48034'22" E26039'21" \\
\hline 36 & SE of Ustia & N48032'31" E26041'57" \\
\hline 37 & Bay of Muksha river & N48034'44" E26042'16" \\
\hline 38 & Tarasivka & N48036'23" E26040'48" \\
\hline 39 & W of Vrublivtsi & N48037'3" E26043'53" \\
\hline 40 & S of Vrublivtsi & N48034'48" E26045'50" \\
\hline 41 & Vrublivtsi & N48036'27" E26045'43" \\
\hline 42 & Kytaihorod & N48038'20" E26047'20" \\
\hline 43 & Demshyn & N48037'6" E26049'54" \\
\hline 44 & Subich & N48035'41" E26049'47" \\
\hline 45 & Kolodiivka - by the Dniester river & N48035'37" E26056'56" \\
\hline 46 & SE of Kolodiivka & N48035'44" E26056'30" \\
\hline 47 & Bakota & N48035'7" E2700'9" \\
\hline
\end{tabular}

